Article

\title{
An Innovative System for Maize Cob and Wheat Chaff Harvesting: Simultaneous Grain and Residues Collection
}

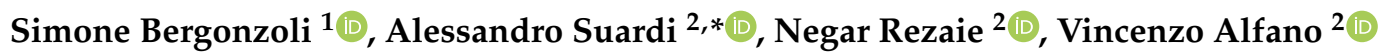 \\ and Luigi Pari ${ }^{2}$ (D) \\ 1 Consiglio per la Ricerca in Agricotura e l'Analisi dell'Economia Agraria (CREA), \\ Centro di Ricerca Ingegneria e Trasformazioni Agroalimentari, 24047 Milan, Italy; \\ simone.bergonzoli@crea.gov.it \\ 2 Consiglio per la Ricerca in Agricotura e l'Analisi dell'Economia Agraria (CREA), \\ Centro di Ricerca Ingegneria e Trasformazioni Agroalimentari, 00015 Rome, Italy; \\ negar.rezaei@crea.gov.it (N.R.); vincenzo.alfano@crea.gov.it (V.A.); luigi.pari@crea.gov.it (L.P.) \\ * Correspondence: alessandro.suardi@crea.gov.it
}

Received: 14 February 2020; Accepted: 3 March 2020; Published: 9 March 2020

\begin{abstract}
Maize and wheat are two of the most widespread crops worldwide because of their high yield and importance for food, chemical purposes and livestock feed. Some of the residues of these crops (i.e., maize cob and wheat chaff) remain in the field after grain harvesting. In Europe, just maize cob and grain chaff could provide an annual potential biomass of $9.6 \mathrm{Mt}$ and $54.8 \mathrm{Mt}$, respectively. Collecting such a biomass could be of interest for bioenergy production and could increase farmers income. Progress in harvest technology plays a key role in turning untapped by-products into valuable feedstocks. This article presents a study of the performance and the quality of the work of Harcob, an innovative system developed for maize cob collection. Furthermore, the feasibility of using the Harcob system to also harvest wheat chaff during wheat harvesting was also verified. The results showed that it was possible to harvest $1.72 \mathrm{tha}^{-1}$ and $0.67 \mathrm{t} \mathrm{ha}^{-1}$ of cob and chaff, respectively, without affecting the harvesting performance of the combine. The profit achievable from harvesting the corn cob was around $4 \%$, while no significant economic benefits were observed during the harvesting of wheat chaff with the Harcob system. The use of cereal by-products for energy purposes may allow the reduction of $\mathrm{CO}_{2}$ from fossil fuel between 0.7 to $2.2 \mathrm{t} \mathrm{CO}_{2} \mathrm{ha}^{-1}$. The Harcob system resulted suitable to harvest such different and high potential crop by-products and may represent a solution for farmers investing in the bioenergy production chain.
\end{abstract}

Keywords: bioenergy; crop by-products; harvesting methods; maize cob; wheat chaff; combine harvesting

\section{Introduction}

Bioenergy plays a significant role in climate change mitigation [1] by replacing fossil fuels for energy production. The agricultural sector is one of the main suppliers of biomass through planting specific bioenergy crops or using cropland residues [2]. This component of crop is constituted by the non-edible plant parts that are not collected and usually left on the field [3]. Considering the European Renewable Energy Directive (RED II, directive 2018/2001/EU), the advantages of using agricultural residues for energy production are, on the one hand, the non-need for additional land and the non-competition with the food industry, and on the other hand to turn an untapped product with a disposal cost, into an economic advantage for farmers. Hence, bioenergy is a tool to improve the economic and environmental sustainability of agricultural sector. A potential source of biomass is represented by the residues of wheat, spelt (Triticum ssp., L.), and maize (Zea mays L.) [4,5]. Indeed, 
the EU-28 produced yearly $152 \mathrm{Mt}$ wheat and spelt [6], and chaff, a heterogeneous mixture of glumes, dust, short straw pieces, broken grain seeds, and weed seeds represents a potential biomass of $38 \mathrm{Mt}$ year $^{-1}$. Considering the lowest heating value of chaff of $15.1 \mathrm{MJ} \mathrm{kg}^{-1}$ [7], and the removal rate of 0.33 , for a stable soil balance [8], it is possible to estimate a theoretical energy availability of $191 \mathrm{PJ} \mathrm{year}^{-1}$ [9]. In EU-28 more than 9 Mha of grain maize are cultivated yearly [10]. Considering an average yield of $1.7 \mathrm{tha}^{-1}$ of cobs [11], and a net calorific value of $18.4 \mathrm{MJ} \mathrm{kg}^{-1}$ [11], from corn cobs alone an amount of energy of $281 \mathrm{PJ}_{\text {year }}{ }^{-1}$ could be produced. Moreover, maize cobs have favorable properties, such as high calorific value and low ash content [12]. It is important to reiterate that the impact on soil nutrients and organic matter, and consequently on the of productivity levels should be considered in the planning of residue removal [13]. However, although a relationship between the amount of residue maintained on the soil and the soil organic matter (SOM) was found in previous studies $[14,15]$. due to the low nutrient content in cobs and wheat chaff, their removal is considered unlikely to affect soil fertility $[9,12]$.

Turning residues into a valuable feedstock mainly depends on technological advances of harvesting techniques [12]. In some European regions, there are no markets or is it convenient to collect and use chaff and cob residues, and e on-field spreading or on-field burning are the most common methods to dispose them of, which is environmentally unsustainable [16]. Currently, only maize stalks and wheat straw, after grain harvesting, are cut, windrowed, baled, and brought to a storage site [17]. The maize cobs are rarely used for bioenergy purpose, because of the collecting difficulties and costs as well as for the chaff that remains below the straw and cannot be collected by the baler. The development of one-pass harvest equipment, able to manage corn grain as well as cobs, and possibly capable of collecting other residues such as wheat chaff, could reduce the number of field work operations and cost of collecting feedstocks [18].

The most complex aspect is to separate the cobs from the grain without affecting the harvesting efficiency of the combine. There are two main harvesting methods currently possible: the collection of whole corn cobs, with separation of the fractions on the farm, or the separation of the two fractions, grain and cobs, directly in the field during harvesting. In the first case, the grain and cobs must be separated at farm level using specific sheller machines [19]. On the other hand, the method of separating the two fractions directly during harvesting uses pneumatic and/or physical means to separate and convey the cobs and maize grain into two separate containers and expel the rest of the residues in the field. The maize cobs can be collected either in a cart pulled by the combine harvester or in a hopper mounted on the combine. In general, one-pass cob collection needs less equipment, work and passes over the field than other methods, even less if no wagon is required. Less field passes of the machines also result in less soil compaction, which is known to negatively affect soil productivity. This aspect represents an advantage due to the absence of contaminants such as dirt and rocks in the harvested cobs and its properties that make it suitable for bioenergy [20]. A substantial impulse to use cob for bioenergy can be represented by Harcob, a new harvesting system, developed by the Italian company Agricinque of Racca group (Marene, $\mathrm{CN}$, Italy). The system consists of a device to separate maize cobs and from the other residues (leaves, stem, culm, etc.) and an additional tank $\left(9 \mathrm{~m}^{3}\right)$ for storing collected materials. The system is patented and already commerciallized, but the use of this machine to harvest wheat chaff is not yet well developed. In Europe, there is currently no established practice to collect chaff during harvesting, even if there are already technologies developed for its baling together with straw, or separating it as a bulk product [21]. The collection and removal of chaff also represents an herbicide-free weed management technique, as chaff contains most of the harvested weed seeds. Chaff collection can prevent the weed seeds from entering the soil and reduce the spread of weed patches.

The purposes of the trial reported here were: (1) to evaluate the operating parameters of the Harcob system, the quality and effectiveness of its work during cob harvesting, (2) to verify the possibility of using the same combine harvester to gather wheat chaff (although it was developed to harvest the maize cob) with a new configuration. Moreover, an economic analysis of the harvesting 
of the two crop by-products was also performed. This approach will foster the utilization of two untapped biomass sources simplify the harvesting and reducing its cost.

\section{Materials and Methods}

\subsection{Study Site}

The study was conducted in October 2018 and July 2019 in the Northern Italy at Revello (44.709920 $\mathrm{N}$ and $7.435711 \mathrm{E})$, Cuneo province, for the harvesting of maize cob and wheat chaff, respectively. The farm is oriented to dairy farming and has a biogas power plant of $250 \mathrm{kWe}$ fed by cow manure and litter, and maize residues (cob and stalks).

\subsection{HarvestingSystem Harcob}

The test was carried out using a modified axial-flow combine harvester (Axial-flow 7130; Case IH, Racine, WI, USA), capable of harvesting separately the maize grains and threshed cobs. The combine was equipped with a specific cob harvesting device, comprising a threshing and separation system, a dedicated cob tank and an unloading device (Figure 1).

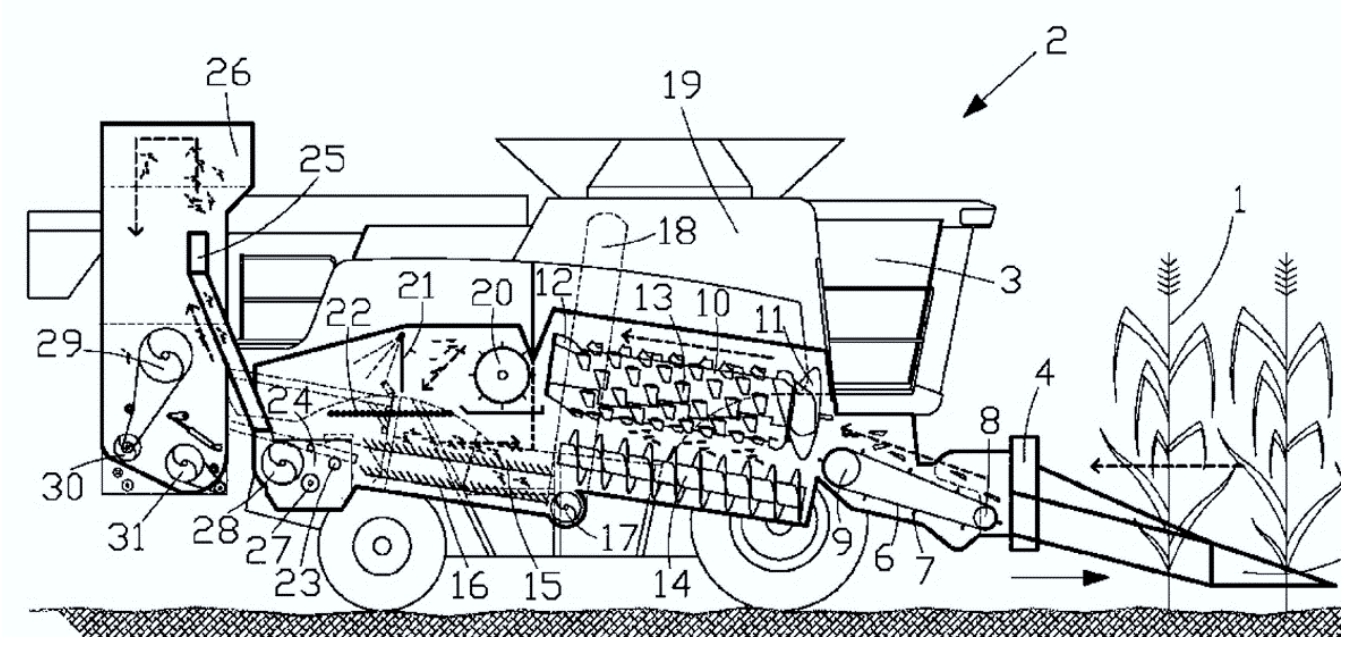

Figure 1. Scheme of the Harcob system for harvesting cobs applied to an axial combine harvester. Reproduced from patent n. EP2668838B1, Racca G. and Racca S. (Current Assignee: Gruppo Racca Srl.)-European Patent Office: 2012.

Crop residues (cob and chaff) are discharged at the distal end of the sieve, at the end of the traditional trashing system of the combine, directly on a transversal auger which feeds a system for chipping the biomass and pneumatically conveying the chips into a duct that terminates in the upper portion of a container arranged on the rear part of the machine. Three augers driven in rotation by hydraulic motors are arranged in the cylindrical container, of which: an auger in the central portion and a lower auger for continuously mixing chips to prevent them from compacting, thus making discharge faster; and a vertical auger that takes the product from the bottom of the container and conveys it upwards for it to be collected. The cob and the chaff are stored till are unloaded with an innovative auger system ensuring no blocking problems and allowing the discharging of cob (as well as chaff) and grain at the same time.

\subsection{Pre-harvesting Activities}

Both maize cob and wheat chaff harvesting tests were carried out following the same data collection methodology. Each test was performed in three blocks (replicates), belonging to the same 
field, of about 0.5 ha each. The combine harvester during the harvesting of maize and wheat has been set according to Table 1 :

Table 1. Axial Flow combine harvester (CASE IH Axial Flow 7088, Racine, WI, USA) settings used during harvesting of maize and wheat.

\begin{tabular}{lcc}
\hline Crop & Wheat & Maize \\
\hline Rotor Speed (rpm) & \multicolumn{2}{c}{750} \\
\hline Gap between Rotor and Separator (mm) & 15 & \multicolumn{2}{c}{20} \\
\hline Cleaning Fan Speed (rpm) & \multicolumn{2}{c}{540} \\
Spreader Speed (rpm) & \multicolumn{2}{c}{560} \\
\hline Openings of Upper Sieve (mm) & 17 & \\
Openings of Lower Sieve (mm) & 14 & 9 \\
\hline
\end{tabular}

Furthermore, before starting the wheat harvesting test the combine was modified as follows: the maize sieve $(41 \mathrm{~mm})$ was changed according to the dimension of the wheat seeds $(28 \mathrm{~mm})$. The crushing elements (knives) of the beating cylinder were also changed (Figure 2).
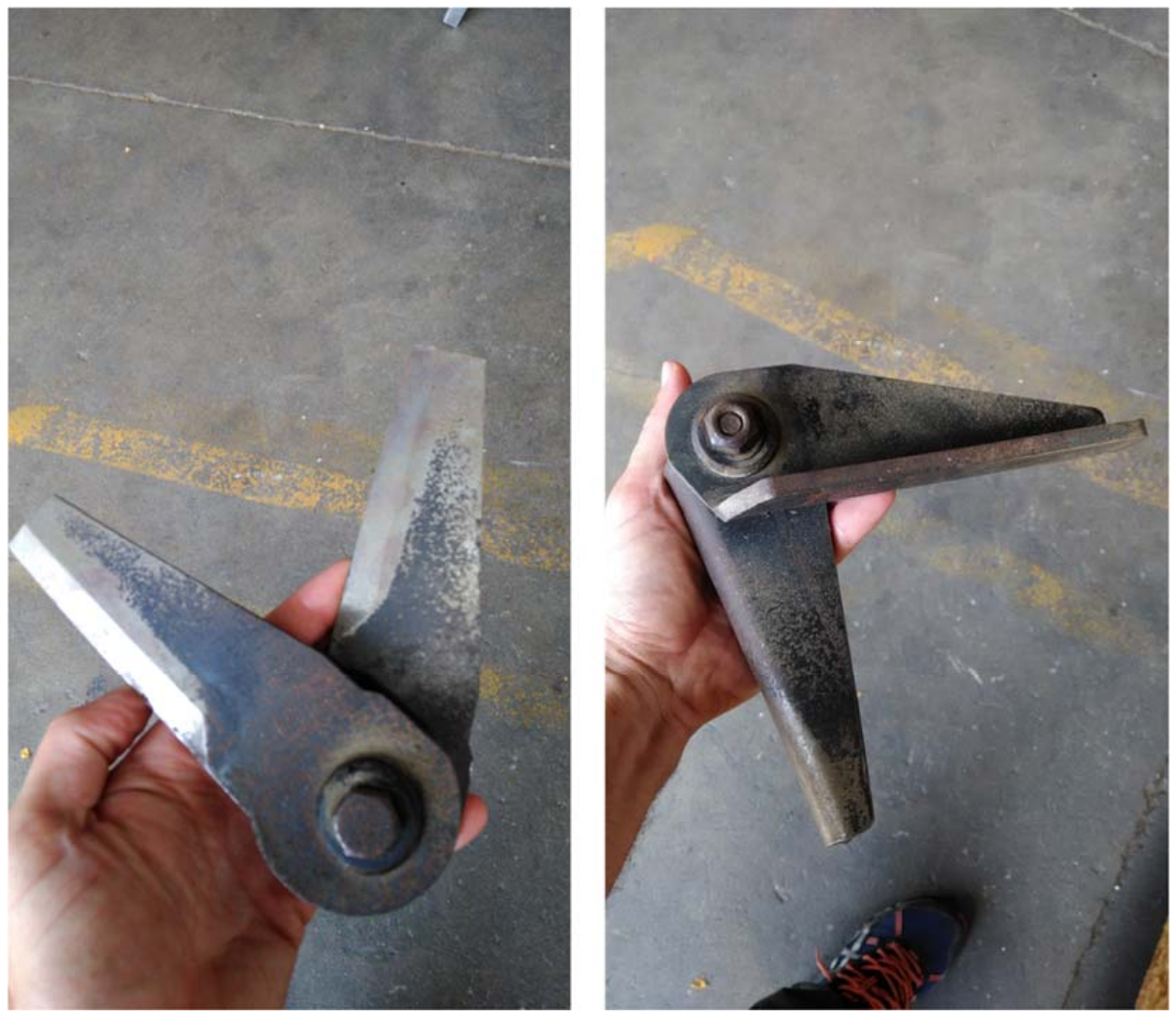

Figure 2. Knives for harvesting wheat chaff (left) and maize cob (right).

The modification must be view as an adaptation of the harvesting system to the different crop.

Pre-harvesting measurements were performed to determine plant characteristics, the total biomass available and the dry matter content in the different plant fractions (seeds, chaff/cob and straw). The pre-harvesting activities were the following:

- Ten sample areas $\left(1 \mathrm{~m}^{2}\right.$ each) randomly chosen, corresponding to $10 \mathrm{~m}^{2}$ in total, were hand harvested. The sample plot was chosen far from the edges to avoid the overestimation due to 
the "edge effect". The plants from the sampling areas were collected as whole plants from the ground level.

- Plants of each sample area were weighed directly in field using a precision scale.

Pre-harvesting data were necessary to determine the total potential biomass available, the amount of biomass losses due to cut height (stubble), and the harvesting losses when the harvesting stage was completed. Wheat and maize ears of each sample area were bagged and shipped to CREA institute in order to determine the single fractions using the laboratory thresher (PLOT 2375 Thresher, Cicoria Company, San Gervasio, Italy).

Three samples of grain, chaff/cob and straw were randomly collected in each experimental field, weighed and stored into vacuum-packs to measure the moisture content. Biomass moisture content (MC) was determined according to ISO 18134-2:2017 [22]. The bulk densities $\left(\mathrm{kg} \mathrm{m}^{-3}\right)$ of the loose biomass of the cob/chaff stored in the Harcob tank was assessed by taking 10 randomly selected samples and was measured according to ISO 17828:2015 [23].

\subsubsection{Harvesting System Productivity}

The biomass remaining in the stubble was assessed by measuring the average cut height that was evaluated by measuring 100 random cut heights transversally to the field for each block. The working time study was performed according to the Comité International d'Organisation Scientifique du Travail en Agriculture (CIOSTA) methodology and the recommendations from the Italian Society of Agricultural Engineering (A.I.I.A.) 3A R1 [24]. Harvested areas were measured as well as the machines' operation time, and yield obtained per each experimental field during the harvesting tests in order to calculate the theoretical field capacity (TFC, ha h${ }^{-1}$ ), the effective field capacity $\left(\mathrm{EFC}, \mathrm{ha} \mathrm{h}^{-1}\right.$ ) of the equipment used and their field efficiency (FE, \%) and material capacity (MC, $\mathrm{Mg} \mathrm{h}^{-1}$ ).

The field capacity corresponds to the number of hectares that can be harvested per hour and its measurement is used to schedule field operations, labor, power units, and to assess machine operating costs. The effective field capacity (EFC) of a machine in the field was calculated by dividing the hectare completed by the hours of actual field time. TFC depends only on the full operating width of the machine and the average travel speed in the field representing the maximum possible FC that can be obtained at the given field speed and full operating width of the machine is being utilized. EFC is less than TFC as a result of the various delays that may occur in the field during the work. The ratio of EFC to TFC represent the machine's FE.

FE is expressed as the percentage of a machine's TFC actually achieved under real conditions. It accounts for overlapping (failure to utilize the full operating width of the machine) and many other time delays like emptying grain and residues, traveling, turning, refilling the fuel tank, making adjustments, waiting for trucks and stops for the operator to rest. Other idle times due to activities that occur outside the field, such as travel to and from the field, major repairs or daily service, are not included in FE measurement.

The MC of harvesting machines is often measured by the quantity of material harvested per hour $\left(\mathrm{t} \mathrm{h}^{-1}\right)$. It is obtained multiplying the machine's EFC and the average yield of crop per hectare.

Fuel consumption was recorded by using the measuring system of the combine harvester.

\subsubsection{Harvesting Lost Calculation and Statistical Analysis}

Grain and residues of both maize and wheat were harvested per each block and weighed separately in the farm scale by using different trailers. After wheat straw baling, the bales produced from each experimental block were weighed. The biomass losses were assessed differently for wheat chaff and maize cob.

Concerning wheat chaff, losses were measured by knowing the total biomass available in the field (assessed during the pre-harvesting stage), the biomass left in the field due to the cut height (assessed during post-harvesting stage) and the grain and by-product harvested and baled, employing the following formula: 


$$
\text { Harvesting losses }\left(\mathrm{t} \mathrm{ha}^{-1}\right)=\mathrm{Rph}-\mathrm{Se}-\mathrm{St}-\mathrm{B}-\mathrm{T}
$$

where Rph $=$ Total amount of biomass assessed in pre-harvesting stage $\left(\mathrm{t} \mathrm{ha}^{-1}\right) ; \mathrm{Se}=$ amount of seeds $\left(\mathrm{t} \mathrm{ha}{ }^{-1}\right) ;$ St $=$ stubble $\left(\mathrm{t} \mathrm{ha}^{-1}\right)\left(\right.$ wheat/maize stalks $\left(\mathrm{t} \mathrm{ha}{ }^{-1}\right) \times$ cut height $\left.(\mathrm{w} \%)\right) ; \mathrm{B}=$ amount of baled residue $\left(\mathrm{tha}^{-1}\right)$ and $\mathrm{T}=$ amount of chaff collected $\left(\mathrm{t} \mathrm{ha} \mathrm{a}^{-1}\right)$.

Maize cob harvesting losses were assessed by collecting and weighing the cob biomass left on the ground. Three random $10 \mathrm{~m}^{2}$ plots were chosen per each block. Then, cobs present in each plot were collected and weighted with a portable dynamometer. Therefore, harvesting losses (\%) were estimated as the ratio of residue losses $\left(\mathrm{Mg} \mathrm{ha}^{-1}\right)$ to the sum of biomass yield $\left(\mathrm{Mg} \mathrm{ha}^{-1}\right)$ and residue losses $\left(\mathrm{Mg} \mathrm{ha}^{-1}\right)$ for each block. The total biomass yield potential was calculated summing the net biomass yield and biomass losses $\left(\mathrm{Mg} \mathrm{ha}^{-1}\right)$.

\subsection{Harvesting Cost Analysis}

Ownership and operating costs were the focus of the economic analysis. Standard values provided by the CRPA methodology [25] and the data collected during the field tests (primary data) were used during the machine operating cost evaluation. Furthermore, data measured during the field tests was validated by interviews with agroindustry owners and their usual suppliers who provided additional cost items used in the cost analysis.

The hourly costs for all the equipment tested during the harvesting were calculated for both cereal crops according to $[25,26]$. Table 2 reports the parameters used during the cost analysis of the harvesting systems tested.

Table 2. Economic parameters used for the cost analysis of cereal straw and chaff, and Maize cob collections using Harcob technology.

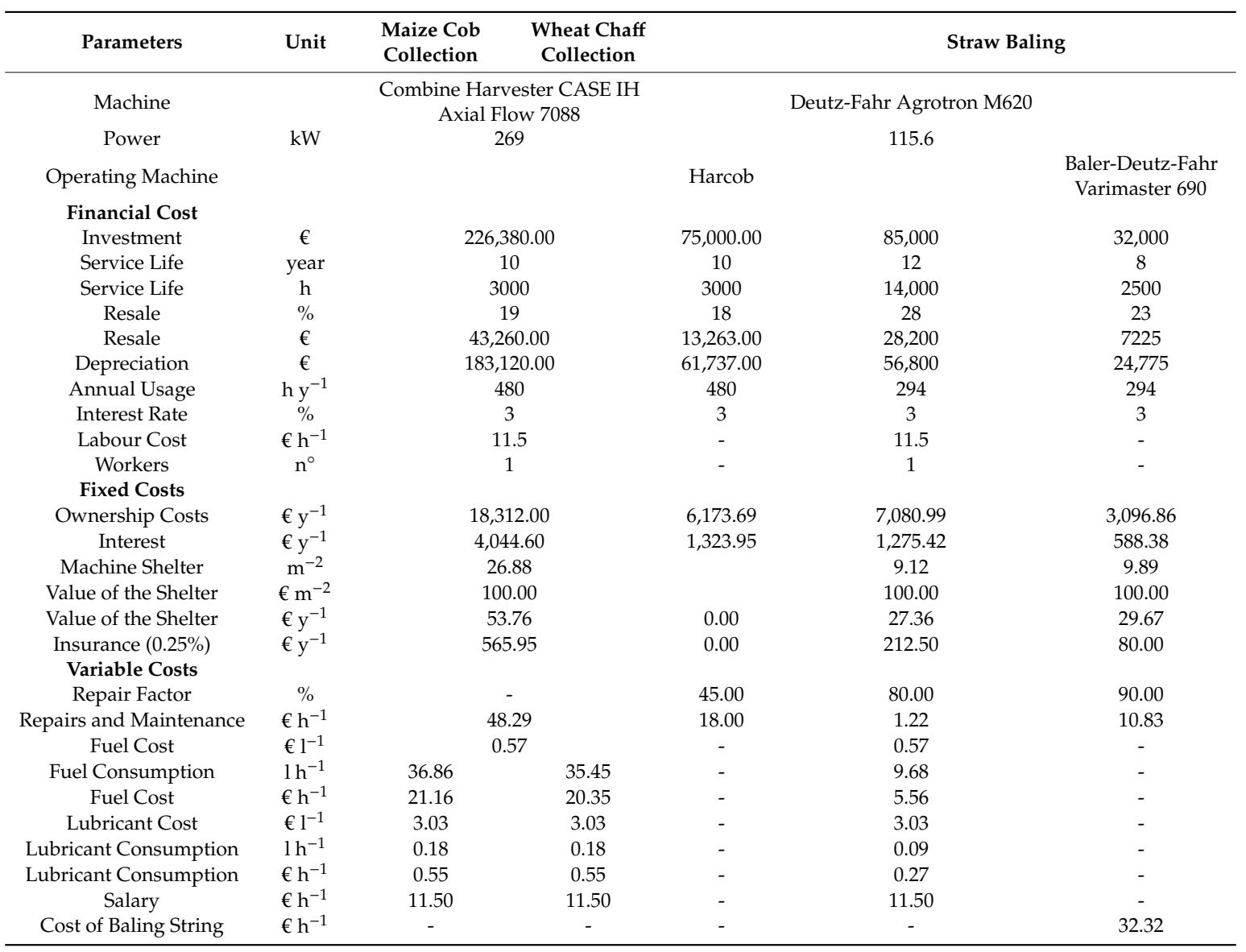


The calculation of the operating costs was per hour of work carried out, per unit area and per ton of product harvested. The share of harvesting costs was carried out through the market value [27] of each product and co-product produced according to Table 3. The economic allocation, per harvesting phase (combine harvesting and baling), comes from the ratio between each product revenue on the total revenues obtained, according to the following formula:

$$
\mathrm{Ea}=\frac{\mathrm{Mp} * \mathrm{Y}_{\mathrm{i}}}{\sum_{\mathrm{i}=1}^{3} \mathrm{R}_{\mathrm{i}}}
$$

where Ea = Economic allocation of each product or co-product (i.e., grain, straw, chaff and cob) per harvesting phase (combine harvesting or baling); $\mathrm{Mp}=$ Market price of each product or co-product; $Y_{i}=$ Yield of each product or co-product and $R_{i}=$ Revenue obtained by multiplying $M p \times Y_{i}$.

Table 3. Economic allocation used for the cost analysis of products and by-products collected during both tests and each harvesting phase, with Harcob technology.

\begin{tabular}{|c|c|c|c|c|c|}
\hline Product & $\begin{array}{l}\text { Market Price } \\
\qquad\left(€ \mathbf{t}^{-1}\right)\end{array}$ & $\begin{array}{c}\text { Yield } \\
\left(\mathrm{t} \mathrm{ha}^{-1}\right)\end{array}$ & $\begin{array}{l}\text { Revenue } \\
\left(€ \mathrm{ha}^{-1}\right)\end{array}$ & $\begin{array}{c}\text { Economic Allocation } \\
\text { for Combine Harvester } \\
(\%)\end{array}$ & $\begin{array}{c}\text { Economic Allocation } \\
\text { for Baling } \\
(\%)\end{array}$ \\
\hline $\begin{array}{l}\text { Wheat } \\
\text { seed }\end{array}$ & 198.50 & 10.93 & 2169.60 & $88 \%$ & $0 \%$ \\
\hline Straw & 50.00 & 5.48 & 274.00 & $11 \%$ & $100 \%$ \\
\hline Chaff & 50.00 & 0.67 & 33.5 & $1 \%$ & $0 \%$ \\
\hline Total & & 17.08 & 2477.11 & $100 \%$ & $100 \%$ \\
\hline Product & $\begin{array}{l}\text { Market price } \\
\qquad\left(€ t^{-1}\right)\end{array}$ & $\begin{array}{l}\text { Yield } \\
\left(\mathrm{t} \mathrm{ha} \mathrm{h}^{-1}\right)\end{array}$ & $\begin{array}{l}\text { Revenue } \\
\left(€ \text { ha }^{-1}\right)\end{array}$ & \multicolumn{2}{|c|}{ Economic Allocation for Combine Harvester (\%) } \\
\hline Maize seed & 185.00 & 13.12 & 2427.20 & \multicolumn{2}{|c|}{$96 \%$} \\
\hline Cob & 65.00 & 1.72 & 111.80 & \multicolumn{2}{|c|}{$4 \%$} \\
\hline Total & & 14.84 & 2539.00 & \multicolumn{2}{|c|}{$100 \%$} \\
\hline
\end{tabular}

\subsection{Avoided $\mathrm{CO}_{2}$ Emission From Fossil Fuel}

In order to evaluate the $\mathrm{CO}_{2}$ emissions from fossil fuel combustion avoided per unit area ( $\mathrm{t} \mathrm{CO} \mathrm{Ch}^{-1}$ ) using cobs and chaff for bio-energies, the equivalent energy production per residue was calculated as follows:

$$
\mathrm{ER}=\mathrm{Yi} \times \mathrm{NC}
$$

where: $\mathrm{ER}=$ Energy content in residue per unit area $\left(\mathrm{MJ} \mathrm{ha}^{-1}\right) ; \mathrm{Yi}=$ Yield of each residue collected $\left(\mathrm{kg} \mathrm{ha}^{-1}\right)$ and $\mathrm{NC}=$ net calorific value of the residue $\left(\mathrm{MJ} \mathrm{kg}^{-1}\right)$.

Considering a net calorific value of diesel of $38.6 \mathrm{MJ}^{-1}$, the diesel equivalent per unit area $\left(1 \mathrm{ha}^{-1}\right)$ to residue collected was calculated as follows:

$$
\mathrm{DE}=\mathrm{ER} / \mathrm{DD}
$$

where $\mathrm{DE}=$ diesel equivalent per unit area $\left(\mathrm{l} \mathrm{ha}^{-1}\right)$; ER $=$ energy content in residue per unit area $\left(\mathrm{MJ} \mathrm{ha}^{-1}\right) ; \mathrm{DD}=$ net calorific value of diesel $\left(\mathrm{MJ}^{-1}\right)$.

Considering that $2.65 \mathrm{Kg} \mathrm{CO}_{2}$ are emitted per liter of Diesel consumed $\left(\mathrm{kg} \mathrm{CO}_{2} \mathrm{l}^{-1}\right)$, the avoided emission of $\mathrm{CO}_{2}$ due to bioenergy produced per residue collected was calculated according to the following formula:

$$
\mathrm{AC}=\mathrm{D} \times \mathrm{EC}
$$

where $\mathrm{AC}=$ avoided emission of $\mathrm{CO}_{2}$ due to bioenergy produced per residue collected $\left(\mathrm{kg} \mathrm{CO}_{2} \mathrm{ha}^{-1}\right)$; $\mathrm{DE}=$ Diesel equivalent per unit area $\left(\mathrm{l} \mathrm{ha}^{-1}\right) ; \mathrm{EC}=$ emission of $\mathrm{CO}_{2}$ per liter of diesel $\left(2.65 \mathrm{Kg} \mathrm{CO}_{2} \mathrm{l}^{-1}\right)$. 


\section{Results}

\subsection{Maize Seeds and Cobs Harvesting Test}

The average value of the stem diameter was $2.3( \pm 1.5) \mathrm{cm}$ with a maximum value of $3.3 \mathrm{~cm}$. The plant height showed a great variability ranging between 155 and $420 \mathrm{~cm}$ with an average value of $325.8( \pm 31.9) \mathrm{cm}$. The average weight of the total biomass was $50.7( \pm 6.4) \mathrm{t} \mathrm{ha}^{-1}$, showing a great variability ranging between 42.8 to $55.1 \mathrm{t} \mathrm{ha}^{-1}$. The ears yield was $19.5( \pm 2.2) \mathrm{t} \mathrm{ha}^{-1}$ in average with 17.0 and $20.9 \mathrm{t} \mathrm{ha}^{-1}$ of minimum and maximum values respectively. The average value of the ears/biomass ratio was $44.0 \%$. The average value of the leaf moisture content $(\mathrm{MC})$ was $32.5( \pm 2.9) \%$, while the stalks registered value of $72.2( \pm 2.8) \%$. Grain MC showed an average value of $18.9( \pm 2.2) \%$, while cob MC was 32.1( $( \pm 3.4) \%$. The average bulk density of the cob resulted $132.36( \pm 11.58) \mathrm{kg} \mathrm{m}^{-3}$.

\subsubsection{Combine Performance and Quality of the Work-Maize Seeds and Cob Harvesting}

The combine harvester machine equipped with the Harcob system, allowed the collection of $13.12 \mathrm{t} \mathrm{ha}^{-1}$ of grain and $1.72 \mathrm{t} \mathrm{ha}^{-1}$ of maize cobs. The unharvested maize cobs that remained in the field were assessed to be equal to $0.58 \mathrm{t} \mathrm{ha}^{-1}$ ( $25 \%$ of the total potentially harvestable cob biomass). The material capacity was $18.58 \mathrm{t} \mathrm{h}^{-1}$ and $2.31 \mathrm{t} \mathrm{h}^{-1}$ for grain and cob, respectively. The unloading of the maize grain and the cobs takes place at the same time because the cobs' tank has been dimensioned in order to be filled at the same time as the grain tank. This technical feature allows one to keep the unproductive times due to the unloading of the maize seed unchanged even after the introduction of a parallel production process to collect the cobs (Figure 3). The fuel consumption was equal to $27.11 \mathrm{ha}^{-1}$. A summary of the results of the performance test are reported in Table 4.

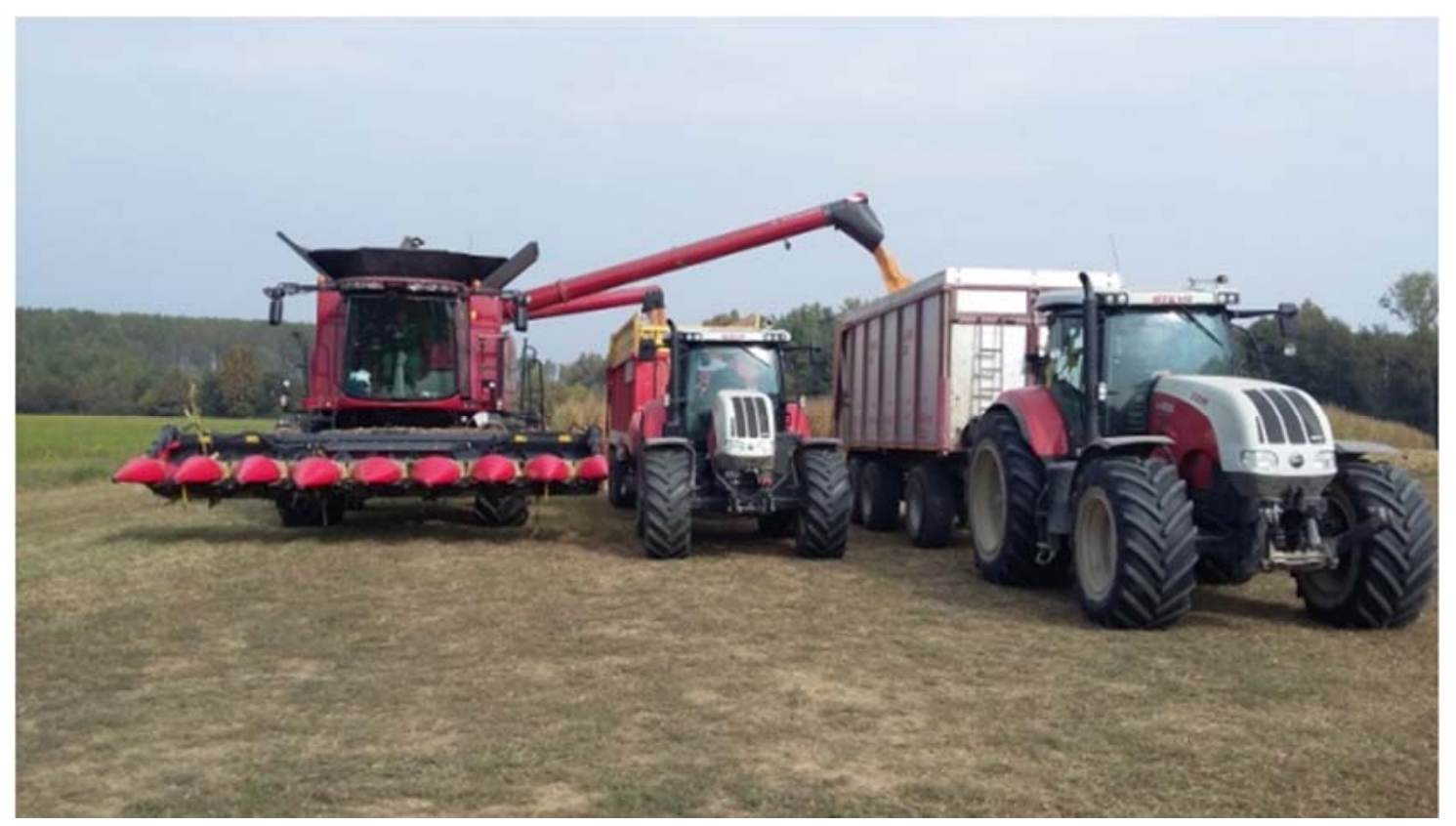

Figure 3. Simultaneous unloading phase of Maize kernel and cob tanks using Harcob system. 
Table 4. Results of the maize and cob harvesting test with combine harvester (CASE IH 7140, Racine, WI, USA) and Harcob system.

\begin{tabular}{|c|c|c|}
\hline Parameters & Mean & Dev. St. \\
\hline Theoretical Field Capacity $\left(\right.$ ha $\mathrm{h}^{-1}$ ) & 1.89 & \pm 0.29 \\
\hline Effective Field Capacity $\left(\right.$ ha $\left.\mathrm{h}^{-1}\right)$ & 1.36 & \pm 0.18 \\
\hline Yield $\left(\mathrm{t}\right.$ grain ha $\left.{ }^{-1}\right)$ & 13.12 & \pm 0.28 \\
\hline Material Capacity $\left(\mathrm{t}\right.$ grain $\left.\mathrm{h}^{-1}\right)$ & 18.58 & \pm 0.13 \\
\hline Yield $\left(\mathrm{t}_{\mathrm{dw}}\right.$ cobs ha $\left.{ }^{-1}\right)$ & 1.72 & \pm 0.23 \\
\hline Material Capacity $\left(\mathrm{t}\right.$ cobs $\mathrm{h}^{-1}$ ) & 2.31 & \pm 0.09 \\
\hline Fuel Consumption $\left(1 \mathrm{ha}^{-1}\right)$ & 27.1 & \pm 4.02 \\
\hline Cob Losses $\left(\mathrm{t} \mathrm{ha}^{-1}\right)$ & 0.58 & \pm 0.23 \\
\hline
\end{tabular}

\subsubsection{Cost Analysis of Maize Seeds and Cobs Harvesting}

The cost analysis of maize harvesting highlighted that the cob collection with the Harcob device is $26 \%$ more expensive compared to the traditional maize seed harvesting in terms of both hourly and per unit area costs (Table 5).

Table 5. Operating costs of maize seeds and cob harvesting. Comparison between traditional and Harcob systems.

\begin{tabular}{|c|c|c|c|c|}
\hline \multicolumn{5}{|c|}{ Maize Seeds and Cob Harvesting Costs with Harcob Technology } \\
\hline & Unit & Corn & Cob & Total Harvesting Cost \\
\hline Market price & $€ \mathrm{t}^{-1}$ & 185 & 65 & \\
\hline Yield & t ha ${ }^{-1}$ & 13.12 & 1.72 & \\
\hline Cost Allocation & $\%$ & $96 \%$ & $4 \%$ & $100 \%$ \\
\hline \multirow{3}{*}{ Combine Harvester + Harcob } & $€ \mathrm{~h}^{-1}$ & 155.95 & 7.18 & 163.13 \\
\hline & $€ \mathrm{ha}^{-1}$ & 114.67 & 5.28 & 119.95 \\
\hline & $€ \mathrm{t}^{-1}$ & 8.74 & 3.07 & \\
\hline \multicolumn{5}{|c|}{ Traditional Maize Seeds Harvesting Costs Without Cob Collection } \\
\hline & Unit & \multicolumn{3}{|c|}{ Corn } \\
\hline Market Price & $€ \mathrm{t}^{-1}$ & \multicolumn{3}{|c|}{185} \\
\hline Yield & $\mathrm{tha}^{-1}$ & \multicolumn{3}{|c|}{13.12} \\
\hline Cost Allocation & $\%$ & \multicolumn{3}{|c|}{$100 \%$} \\
\hline \multirow{3}{*}{ Combine Harvester } & $€ \mathrm{~h}^{-1}$ & \multicolumn{3}{|c|}{129.51} \\
\hline & $€ \mathrm{ha}^{-1}$ & \multicolumn{3}{|c|}{95.23} \\
\hline & $€ \mathrm{t}^{-1}$ & \multicolumn{3}{|c|}{7.26} \\
\hline
\end{tabular}

The higher investment required to purchase the Harcob system also has an impact on the cost of corn $\left(€ \mathrm{t}^{-1}\right)$ which resulted $20 \%$ higher than harvesting without Harcob. However, the Harcob system produced a revenue of $111.80 € \mathrm{ha}^{-1}$ higher than the traditional harvesting system permitting the collection of about $1.7 \mathrm{t} \mathrm{cob}$ per hectare (Table 2). Furthermore, subtracting the only harvesting costs to the total revenues obtained with each harvesting system, with Harcob the profit was $2419.05 €$ ha $^{-1}$ while with the traditional harvesting system the difference was $2331.97 € \mathrm{ha}^{-1}$. With Harcob it was possible to obtain an income of $87.08 € \mathrm{ha}^{-1}(4 \%)$ higher than using the traditional harvesting system without Harcob.

\subsection{Wheat Seeds and Chaff Harvesting Test}

Pre-harvesting test permitted to assess a total amount of biomass per hectare of $25.9( \pm 0.34)$ tons, of which $11.5( \pm 1.01)$ tons of grain and $2.48( \pm 0.11)$ tons of chaff. The amount of straw was estimated in $8.58( \pm 1.08)$ tons per hectare of which $3.38( \pm 0.48)$ tons of stubble that remained in the soil due to 
the cutting height of the machine. The average value of the straw moisture content was $23.0( \pm 1.4) \%$. Grain and chaff moisture content were $12.4( \pm 0.4) \%$. The average bulk density of the chaff resulted $42.88 \mathrm{~kg} \mathrm{~m}^{-3}$.

\subsubsection{Combine Performance and Quality of the Work-Wheat Seeds and Chaff Harvesting}

The Harcob system was developed for harvesting corn cobs. Given the growing interest of the agricultural, industrial and research sectors in unused wheat residues, once the necessary modifications to be made to the combine already described had been identified, specific harvesting tests were conducted to verify the possibility of also using the Harcob system for the separate harvesting of cereal husks. During the wheat harvesting tests the grain and chaff collected were 10.93 and $0.67 \mathrm{t} \mathrm{ha}^{-1}$, respectively. The material capacity was $12.98 \mathrm{t} \mathrm{h}^{-1}$ and $0.79 \mathrm{t} \mathrm{h}^{-1}$ for grain and chaff, respectively. Performance test results are summarized in Table 6.

Table 6. Results of the wheat grain and chaff harvesting test with combine harvester CASE IH 7140 and Harcob system.

\begin{tabular}{ccc}
\hline Parameters & Mean & Dev. St. \\
\hline Theor. Field Capacity $\left(\mathrm{ha} \mathrm{h}^{-1}\right)$ & 1.42 & \pm 0.05 \\
Eff. Field Capacity $\left(\mathrm{ha} \mathrm{h}^{-1}\right)$ & 1.19 & \pm 0.01 \\
Yield $\left.(\mathrm{t} \mathrm{seeds} \mathrm{ha})^{-1}\right)$ & 10.93 & \pm 0.43 \\
Material Capacity $\left(\mathrm{t} \mathrm{seeds}^{-1}\right)$ & 12.98 & \pm 0.66 \\
Yield $\left(\mathrm{t} \mathrm{chaff} \mathrm{ha} \mathrm{ha}^{-1}\right)$ & 0.67 & \pm 0.02 \\
Material Capacity $\left(\mathrm{t} \mathrm{chaff} \mathrm{h}^{-1}\right)$ & 0.79 & \pm 0.02 \\
Fuel Consumption $\left(\mathrm{l} \mathrm{ha}^{-1}\right)$ & 29.86 & \pm 0.31 \\
\hline
\end{tabular}

Results of pre-harvesting and harvesting tests were elaborated in order to define the mass balance and to assess the biomass losses. Harvesting tests carried out on wheat have shown the Harcob system's incapability of effectively separating the wheat chaff from the straw. In particular, the Harcob tank contained about $10 \%$ of straw mixed with chaff. Furthermore, the windrow of residues generated by the combine was made by $50 \%$ of chaff and $50 \%$ of straw.

Due to the results of the harvesting and the impossibility to distinguish chaff from straw, these two biomasses were considered together for the mass balance definition reported in Table 7. Results highlighted $4.87 \%$ of grain losses and $47.06 \%$ of chaff and straw losses (excluding the stubble part that remained uncollected in the soil).

Table 7. Wheat grain and residues losses assessment.

\begin{tabular}{cccc}
\hline Wheat Fractions & $\begin{array}{c}\text { Potential Biomass } \\
\left(\mathbf{t d} \mathbf{w} \mathbf{h a}^{\mathbf{- 1}} \mathbf{)}\right.\end{array}$ & $\begin{array}{c}\text { Harvested Products } \\
(\mathbf{t d w} \text { ha } \mathbf{- 1})\end{array}$ & $\begin{array}{c}\text { Biomass Losses } \\
\mathbf{( \% )}\end{array}$ \\
\hline Grain & 10.2 & 9.7 & 4.87 \\
Chaff & 2.2 & 0.6 & 47.06 \\
Straw & 5.2 & 3.3 & - \\
Stubble & 2.1 & 2.1 & 47.06 \\
Total Residues & 9.5 & 6.0 & \\
\hline
\end{tabular}

* Fractions of the biomass available per unit area assessed with pre and post-harvesting analysis.

\subsubsection{Cost Analysis of Wheat Seeds and Residue Harvesting}

The wheat chaff harvesting cost resulted higher than the cob harvesting using the same system (Table 8). The higher investment required to purchase the Harcob system has an impact also on the cost of wheat $\left(€ \mathrm{t}^{-1}\right)$ which is $24 \%$ higher than harvesting without Harcob. Furthermore, Harcob device developed for maize cob harvesting resulted able to collect part of the wheat chaff separately by the straw, but with some chaff losses of about $47 \%$. Comparing the total costs to harvest wheat with and without the Harcob system, it can be observed that the use of Harcob implied an extra cost of 
$14 \%$. In the absence of a chaff market, assuming the market price of chaff comparable to that of straw $\left(50 € \mathrm{t}^{-1}\right)$, the harvesting of chaff with the Harcob system allowed to obtain a revenue of $33.5 € \mathrm{ha}^{-1}$ (Table 3) While, according to the economic allocation used for cost sharing among wheat products reported in Table 3, the profit obtainable by chaff collection with Harcob system resulted $31.4 €$ ha $^{-1}$.

Table 8. Operating costs of wheat grain and residues harvesting. Comparison between traditional and Harcob systems.

\begin{tabular}{|c|c|c|c|c|c|}
\hline \multicolumn{6}{|c|}{ Wheat Harvesting Cost using Harcob Technology } \\
\hline & Unit & Grain & Straw & Chaff & Total Cost Per Phase \\
\hline Market Rice & $€ \mathrm{t}^{-1}$ & 198.50 & 50.00 & 50.00 & \\
\hline Yield & tha ${ }^{-1}$ & 10.93 & 5.48 & 0.67 & \\
\hline Cost Allocation & $\%$ & $88 \%$ & $11 \%$ & $1 \%$ & $100 \%$ \\
\hline \multirow{3}{*}{ Combine Harvester + Harcob } & $€ \mathrm{~h}^{-1}$ & 142.04 & 17.94 & 2.19 & 162.18 \\
\hline & $€ \mathrm{ha}^{-1}$ & 139.26 & 17.59 & 2.15 & 159.00 \\
\hline & $€ \mathrm{t}^{-1}$ & 12.74 & 3.21 & 3.21 & \\
\hline Cost Allocation & $\%$ & - & $100 \%$ & - & $100 \%$ \\
\hline \multirow{3}{*}{ Tractor + Baler } & $€ \mathrm{~h}^{-1}$ & - & 112.71 & - & 112.71 \\
\hline & $€ \mathrm{ha}^{-1}$ & - & 36.15 & - & 36.15 \\
\hline & $€ \mathrm{t}^{-1}$ & - & 6.60 & - & 6.60 \\
\hline \multirow{3}{*}{ Total Cost of the Harvesting System } & $€ \mathrm{~h}^{-1}$ & 142.04 & 130.65 & 2.19 & 274.88 \\
\hline & $€$ ha $^{-1}$ & 139.26 & 53.74 & 2.15 & 195.14 \\
\hline & $€ \mathrm{t}^{-1}$ & 12.74 & 9.81 & 3.21 & \\
\hline \multicolumn{6}{|c|}{ Traditional Wheat Harvesting Cost Without Chaff Collection } \\
\hline & Unit & Grain & Straw & Chaff & Total Cost Per Phase \\
\hline Market Price & $€ \mathrm{t}^{-1}$ & 198.50 & 50.00 & 0.00 & \\
\hline Yield & tha ${ }^{-1}$ & 10.93 & 5.48 & 0.00 & \\
\hline Cost Allocation & $\%$ & $89 \%$ & $11 \%$ & $0 \%$ & $100 \%$ \\
\hline \multirow{3}{*}{ Combine Harvester } & $€ \mathrm{~h}^{-1}$ & 114.15 & 14.41 & 0.00 & 128.56 \\
\hline & $€$ ha $^{-1}$ & 111.91 & 14.13 & 0.00 & 126.04 \\
\hline & $€ \mathrm{t}^{-1}$ & 10.24 & 2.58 & 0.00 & \\
\hline Cost Allocation & $\%$ & - & $100 \%$ & - & $100 \%$ \\
\hline \multirow{3}{*}{ Tractor + Baler } & $€ \mathrm{~h}^{-1}$ & - & 112.71 & - & 112.71 \\
\hline & $€$ ha $^{-1}$ & - & 36.15 & - & 36.15 \\
\hline & $€ \mathrm{t}^{-1}$ & - & 6.60 & - & 6.60 \\
\hline \multirow{3}{*}{ Total Cost of the Harvesting System } & $€ \mathrm{~h}^{-1}$ & 114.15 & 127.12 & 0.00 & 241.27 \\
\hline & $€ \mathrm{ha}^{-1}$ & 111.91 & 50.28 & 0.00 & 162.19 \\
\hline & $€ \mathrm{t}^{-1}$ & 10.24 & 9.18 & 0.00 & \\
\hline
\end{tabular}

\subsection{Impact of Residuals on Cemissions}

The collection of agricultural residues such as cobs and chaff for energy purposes implies avoided $\mathrm{CO}_{2}$ emissions due to reduced use of fossil fuels. In this study, considering a net calorific value of $18.4 \mathrm{MJ} \mathrm{kg}^{-1}$ of cob [7] and $15.1 \mathrm{MJ} \mathrm{kg}^{-1}$ of chaff [7], according to the product collected during the tests, the equivalent energy was estimated to be 31,648 and $10,117 \mathrm{MJ} \mathrm{ha}^{-1}$ for cobs and chaff, respectively. This leads to an avoided Diesel consumption of 820 and 2621 ha $^{-1}$ due to cob and chaff for energy production, respectively. Maize cobs and wheat chaff for energy purposes would avoid greenhouse gasses emissions (GHG) from fossil fuel equal to $2.2 \mathrm{t} \mathrm{CO}_{2}$ and $0.7 \mathrm{t} \mathrm{CO}_{2}$, respectively. 


\section{Discussion}

Since the beginning of the nineteenth century, before modern combine harvesters, corn was harvested as a whole ear of corn and shelled afterwards [28,29]. Even if cobs were all collected, harvesting was a labor-intensive job because the grain still had to be threshed. With the increase in harvesting mechanization, the trend had become to leave the cob in the field. It was only in the 1980s that Bargiel et al. developed a first cob collection system based on a mechanical separator that unloaded it onto a towed trailer [30], although, the system still had limits in terms of cob losses that resulted about $31 \%$ considering a cob purity of $89 \%$. The low purity of the cob collected, affected also its bulk density that was $100 \mathrm{~kg} \mathrm{~m}^{-3}$. Since 1980 several studies have analyzed various solutions for the harvesting of corn cobs, sometimes reaching high levels of purity of the harvested product and significantly reducing harvest losses [31], but where multiple passes were necessary, or trailers towed by tractors side-by-side the combine.

Moreover, as noted by [32] the fraction of available stover harvested by conventional means was rather low, between $37 \%$ and $57 \%$. A combined single-pass harvesting system of corn grain and residues in single-pass would further reduce field operations and costs.

Shinners proposed a harvesting system of corn grain and stover in single-pass that resulted 39\% less productive than the conventional grain harvest system. In addition, the authors of the study had highlighted clear difficulties for the system to manage both cereals and residues at the same time [32].

Hence, the Harcob system represents an innovation considering the possibility to perform a single-pass grain and cob harvesting with simultaneous unloading of the products (grain and cob) in two different trailers, without affect the harvesting performance of the combine, and without modifying the harvesting method and costs. The cob harvesting losses of $25 \%$ are comparable with the results of tests performed with an experimental corn cob separation system mounted on a John Deere 9750 STS combine in Iowa (USA), where this parameter ranged between 35\% and 5\% [31].

Harvesting tests were carried out also to collect wheat chaff even if first results highlighted the need for further improvement and modifications due to high losses and the level of impurities measured. The Harcob system was developed to be mounted in axial combine harvesters that can provide lower grain breakage percentage and higher productivity respect to the traditional harvesters with straw walkers but, on the other hand have stronger mechanical action on the straw. Even if Harcob system allows one to collect $0.6 \mathrm{t} \mathrm{ha}^{-1}$ of chaff for bioenergy, the use of Harcob showed $47 \%$ of biomass losses. The amount of biomass losses could be explained by the straw crushing caused by the threshing system of the axial harvester. In fact, once the straw is cut in smaller parts, then the cleaning and ventilation system is not able to discriminate and separate the grain from the chaff and from the straw. The result was that part of the chaff went into the straw windrow.

Even if experiences of chaff harvesting are almost absent in the bibliography, there are already machines on the market developed for the separate collection of chaff and straw, mainly to avoid the spread of weed seeds, but also for their use in animal husbandry or for the production of biofuel and energy $[21,33,34]$. The experience carried out by Pari during chaff and straw collection by means a residue spreader tested in Sweden for chaff and straw baling, showed a residue harvesting losses between $31 \%$ to $47 \%$ [35]. This is to clarify that the harvesting efficiency of the Harcob system was similar to that of a system developed for the spreading of residues and that can partially, by changing the setting, allow a certain admixing of the chaff with the straw. For this reason, improvements will be necessary to optimise chaff harvesting with Harcob, reducing both product losses and increasing the separation capacity of the two fractions.

Even if maize harvesting by Harcob was $25 \%$ more expensive per unit area than a traditional system, it resulted more convenient than contractor harvesting cost in Italy where the harvesting cost varies from 135 to $150 € \mathrm{ha}^{-1}$. According to the test results, in case of maize grain and cobs harvesting, the tested device allows farmers to have a higher profit even if both hourly and per unit area costs are higher than those of a traditional system. Concerning the chaff harvesting costs no information were found for the Italian agricultural sector. However, the cost of wheat harvesting (grain and straw) is 
similar to traditional systems in Central (150-175€ ha ${ }^{-1}$ including straw chopping) and Northern Italy (206-245€ ha ${ }^{-1}$ including straw bailing) [36].

The risk of high bioenergy demand is the impacts of the indirect land use change (ILUC) which may occur when grazing land or farmland previously devoted to food production is turned over to the production of biofuels. This production change may expand agriculture land into areas with high carbon stock (i.e. peatlands, forests and wetlands), causing the release of greenhouse gases $\left(\mathrm{CO}_{2}\right.$ stored in soil and trees) and negating the benefits of using biofuels instead of fossil fuels, in terms of emission savings. Hence, the European Renewable Energy Directive (RED II) faces this risk. Consequently, alternative feedstock to produce bioenergy sources, such as cobs and chaff, are fundamental to sustain the agro-energy production chain.

The impact on the atmospheric $\mathrm{CO}_{2}$ using biomass as fuel is negligible. Biomass utilization on a global scale could contribute to environmental protection, having in mind that biomass sources are $\mathrm{CO}_{2}$-neutral because all the $\mathrm{CO}_{2}$ from biomass combustion is absorbed during new biomass growing to be used for the same purpose [7]. The present study demonstrated that using residues the reduction of $\mathrm{CO}_{2}$ from fossil fuel is ranging from 0.7 to $2.2 \mathrm{t} \mathrm{CO}_{2} \mathrm{ha}^{-1}$. Even if the amount is low, they are very important because they are derived from renewable material.

\section{Conclusions}

Maize cob and wheat chaff are often less expensive untapped residues compared to dedicated energy crops. In fact, both maize cob and cereal chaff are co-products of grain production, and excluding harvest and nutrient replacement, no additional costs are necessary. However, the feasibility of using these feedstocks for bioenergy production is mainly related to the harvest methods used and biomass available and collectable per hectare. The scope of this study was to evaluate the operating parameters of the Harcob system and the quality and effectiveness of its work during cob harvesting and to verify the feasibility of harvesting the wheat chaff through an innovative system (although it was developed to harvest the maize cob). According to the methodology utilized in this study it was possible to harvest $1.72 \mathrm{t} \mathrm{ha}^{-1}$ and $0.67 \mathrm{tha}^{-1}$ of cob and chaff, respectively. This would allow farmers to obtain a revenue of $111 € \mathrm{ha}^{-1}$ from the sale of the cobs corresponding to an increase in profit of $4 \%$ compared to the harvesting of only corn seed using the traditional system. As far as the chaff collection through the use of the Harcob system has not shown real advantages from the economic point of view allowing farmers to obtain an increase in profit close to zero. This result is obviously influenced by the market price of the chaff which in this article has been assumed to be the same as that of straw. Although, the separate collection of the product, the increase in collection efficiency, and the presence of a specific market (for agricultural or industrial use) could make the use of by-product collection systems such as Harcob increasingly economically attractive.

In conclusion, the Harcob system could be considered suitable to harvest such different and high potential crop by-products and may represent a solution for farmers investing in the bioenergy production chain. Furthermore, the possibility of using the same combine harvester for two different cash crops in two different seasons will increase the profitability of the machinery. Aspects related to the improvement of the system for chaff harvesting should be investigated and included in future studies.

Author Contributions: Conceptualization, S.B., A.S. and L.P.; methodology, S.B., V.A.; formal analysis, S.B. A.S.; investigation, L.P.; resources, S.B., A.S. and N.R.; data curation, S.B. and N.R.; writing-original draft preparation, A.S. and N.R.; writing — review and editing, S.B., A.S., N.R., V.A., L.P.; visualization, L.P.; supervision, L.P.; funding acquisition, L.P. All authors have read and agreed to the published version of the manuscript.

Funding: This project has received funding from the European Union's Horizon 2020 research and innovation programme under Grant Agreement No 727961.

Acknowledgments: The work was performed in the framework of the European project AGROinLOG "Demonstration of innovative integrated biomass logistics centres for the Agro-industry sector in Europe". The authors wish to thank Mr Gabriele Racca, and the employees of Giletta farm for the authorization to conduct the tests and for their assistance in performing them and their professionality and availability.

Conflicts of Interest: The authors declare no conflict of interest. 


\section{References}

1. Creutzig, F.; Ravindranath, N.H.; Berndes, G.; Bolwig, S.; Bright, R.; Cherubini, F.; Chum, H.; Corbera, E.; Delucchi, M.; Faaij, A.; et al. Bioenergy and climate change mitigation: An assessment. GCB Bioenergy 2015, 7, 916-944. [CrossRef]

2. Scarlat, N.; Martinov, M.; Dallemand, J.F. Assessment of the availability of agricultural crop residues in the European Union: Potential and limitations for bioenergy use. Waste Manag. 2010, 30, 1889-1897. [CrossRef] [PubMed]

3. Suardi, A.; Bergonzoli, S.; Alfano, V.; Scarfone, A.; Pari, L. Economic Distance to Gather Agricultural Residues from the Field to the Integrated Biomass Logistic Centre: A Spanish Case-Study. Energies 2019, 12, 3086. [CrossRef]

4. Paul, S.; Dutta, A.; Defersha, F. Mechanical and Alkaline Hydrothermal Treated Corn Residue Conversion in to Bioenergy and Biofertilizer: A Resource Recovery Concept. Energies 2018, 11, 516. [CrossRef]

5. Dyjakon, A.; Noszczyk, T.; Smędzik, M. The Influence of Torrefaction Temperature on Hydrophobic Properties of Waste Biomass from Food Processing. Energies 2019, 12, 4609. [CrossRef]

6. Eurostat Main annual crops statistics. Cereal (excluding rise) for the production of grain (including seeds). Most recent data: Further Eurostat information, Main tables and Database 2017. Available online: https://ec.europa.eu/eurostat/tgm/refreshTableAction.do;jsessionid=9RtD-bVDHUXBA82cd_Gfy_ FKm3Do4LUXaoihLaKC-TQKaI-ZSmfS!-755574875?tab=table\&plugin=1\&pcode=tag00047\&language= en (accessed on 6 March 2020).

7. Kiš, D.; Jovičić, N.; Matin, A.; Kalambura, S.; Vila, S.; Guberac, S. Energy value of agricultural spelt residue (Triticum spelta L.)—Forgotten cultures. Teh. Vjesn. Tech. Gaz. 2017, 24, 369-373.

8. Weiser, C.; Zeller, V.; Reinicke, F.; Wagner, B.; Majer, S.; Vetter, A.; Thraen, D. Integrated assessment of sustainable cereal straw potential and different straw-based energy applications in Germany. Appl. Energy 2014, 114, 749-762. [CrossRef]

9. Weiß, B.D.; Glasner, C. Evaluation of the process steps of pretreatment, pellet production and combustion for an energetic utilization of wheat chaff. Front. Environ. Sci. 2018, 6, 36. [CrossRef]

10. Eurostat Grain Maize and Corn-Cob-Mix by Area, Production and Humidity. EU Dataset. Code: TAG00093 Last Update: 13/02/2020 23:00 2019. Available online: https://ec.europa.eu/eurostat/databrowser/view/ tag00093/default/table?lang=en (accessed on 6 March 2020).

11. Halvorson, A.D.; Johnson, J.M.F. Corn cob characteristics in irrigated central great plains studies. Agron. J. 2009, 101, 390-399. [CrossRef]

12. Jansen, C.; Lübberstedt, T. Turning Maize Cobs into a Valuable Feedstock. Bioenergy Res. 2012, 5, $20-31$. [CrossRef]

13. Wilson, G.V.; Dabney, S.M.; McGregor, K.C.; Barkoll, B.D. Tillage and residue effects on runoff and erosion dynamics. Trans. Am. Soc. Agric. Eng. 2004, 47, 119-128. [CrossRef]

14. Blanco-Canqui, H. Crop Residue Removal for Bioenergy Reduces Soil Carbon Pools: How Can We Offset Carbon Losses? Bioenergy Res. 2013, 6, 358-371. [CrossRef]

15. Eleki, K. Soil management, crop rotations, and biomass removal effects on soil organic matter content. Ph.D. Thesis, Iowa State University, Ames, IA, USA, 2007. [CrossRef]

16. Palmieri, N.; Forleo, M.B.; Giannoccaro, G.; Suardi, A. Environmental impact of cereal straw management: An on-farm assessment. J. Clean. Prod. 2017, 142, 2950-2964. [CrossRef]

17. Shinners, K.J.; Binversie, B.N.; Muck, R.E.; Weimer, P.J. Comparison of wet and dry corn stover harvest and storage. Biomass Bioenergy 2007, 31, 211-221. [CrossRef]

18. Johnson, J.M.F.; Wilhelm, W.W.; Karlen, D.L.; Archer, D.W.; Wienhold, B.; Lightle, D.T.; Laird, D.; Baker, J.; Ochsner, T.E.; Novak, J.M. Nutrient removal as a function of corn stover cutting height and cob harvest. BioEnergy Res. 2010, 3, 342-352. [CrossRef]

19. Desai, B.B. Seeds Handbook: Processing and Storage; CRC Press: Boca Raton, FL, USA, 2004; ISBN 1482276429.

20. Maung, T.A.; Gustafson, C.R. The Viability of Harvesting Corn Cobs and Stover for Biofuel Production in North Dakota. Agric. Appl. Econ. Assoc. 2011, 2011,1-41.

21. Pari, L.; Alfano, V.; Scarfone, A.; Bergonzoli, S.; Suardi, A. Best available technologies to harvest cereal chaff. In Proceedings of the 26th European Biomass Conference and Exhibition (EUBCE), Copenhagen, Denmark, 2018. 
22. NSAI. ISO 18134-2:2015, Solid Biofuels—Determination of Moisture content_Oven Dry Method-Part 2: Total Moisture—Simplified Method; NSAI: Vernier, Geneva, Switzerland, September 2015. Available online: https://www.iso.org/standard/61539.html (accessed on 6 March 2020).

23. NSAI. ISO 17828:2015, Solid Biofuels—Determination of Bulk Density; NSAI: Vernier, Geneva, Switzerland, December 2015. Available online: https://www.iso.org/standard/60687.html (accessed on 6 March 2020).

24. Assirelli, A.; Croce, S.; Acampora, A.; Civitarese, V.; Suardi, A.; Santangelo, E.; Pari, L. An innovative system for conditioning biomass sorghum [Sorghum bicolor (L.) moench.]. Trans. ASABE 2013, 56, 829-837.

25. Assirelli, A.; Pignedoli, S. Costo di esercizio delle macchine agricole. Cent. Ric. e Prod. Anim. 2005, 5, 1-10. (In Italian)

26. American Society of Agricultural Engineers. Agricultural Machinery Management; American Society of Agricultural Engineers: St. Joseph, MI, USA, 2000; pp. 344-349.

27. Camera di Commercio di Modena (Chamber of Commerce of Modena) Listino dei prezzi all'ingrosso rilevati sul mercato di Modena nella settimana dal 16 luglio al 22 luglio 2019 (List of Wholesale Prices Recorded on the Modena Market in the Week from 16 July to 22 July 2019). 2019. Available online: https://www.mo.camcom.it/tutela-del-mercato/borsamerci/listini/listino-dei-prezzi-allingrossorilevati-sul-mercato-di-modena-nella-settimana-dal-16-al-22-luglio-2019 (accessed on 6 March 2020).

28. Snow, K.T. Corn Picker. U.S. Patent No. 2,974,465, 14 March 1961.

29. Stone, J.A. Corn Harvester and Husker. U.S. Patent US 786,239, 5 May 1905.

30. Bargiel, D.A.; Liljedahl, B.; Richey, C.B. A combine cob saver. Am. Soc. Agric. Biol. Eng. 1982, 25, 544-548. [CrossRef]

31. Johnson, J.K. Integration of a cob separation system into a biomass harvesting combine. Grad. Theses Diss. Iowa State Univ. 2010, 11241, 67.

32. Shinners, K.J.; Bennett, R.G.; Hoffman, D.S. Single-and two-pass corn grain and stover harvesting. Trans. $A S A B E$ 2012, 55, 341-350. [CrossRef]

33. Unger, J.S.; Glasner, C. Cost analysis of chaff harvesting concepts in Germany. Agronomy 2019, 9, 579. [CrossRef]

34. Pari, L.; Alfano, V.; Scarfone, A.; Bergonzoli, S.; Suardi, A. Agricultural byproducts valorization in the circular economy: The case of chaff. In Proceedings of the Book of Abstracts, Olsztyn, Poland, 24-26 September 2019; Wydawnictwo Uniwersytetu Warmińsko-Mazurskiego: Olsztyn, Poland, 2019.

35. Pari, L.; Scarfone, A.; Lundin, G.; Gunnarsson, C.; Bergonzoli, S.; Alfano, V.; Lazar, S.; Suardi, A. Combined harvesting of chaff and straw for bioethanol production: The first experience on wheat in Sweden. In Proceedings of the 26th European Biomass Conference and Exhibition, Copenhagen, Denmark, 14-18 May 2018; pp. 289-293.

36. C.A.I. (Confederazione Agromeccanici e Agricoltori Italiani) Price List Net of VAT (10\%) of Agricultural Mechanic Work on Behalf of Third Parties Valid for the Province of Alessandria for the Year 2017; European Automobile Manufacturers Association: Roma, Italy, 2017, Sheet no. 2-Price Listof 22.06.2017. Available online: http://www.confagricolturalessandria.it/documenti/listprez_giugno2017_APTMA_ALESSANDRIA_ AL.pdf (accessed on 6 March 2020).

(C) 2020 by the authors. Licensee MDPI, Basel, Switzerland. This article is an open access article distributed under the terms and conditions of the Creative Commons Attribution (CC BY) license (http://creativecommons.org/licenses/by/4.0/). 